\title{
Modelling profile and shape evolution during hot rolling of steel strip*
}

\author{
P.C. Zambrano**, L.A. Leduc ${ }^{* * * *}$ and R. Colás***
}

Abstract

Keywords

Profile and shape control are required to assure the dimensional quality of rolled strip. Occurrence of waves either at the edges or centre of strips is attributed to inconsistency between the entry and exit cross-section profiles of the stock within a given rolling pass. The exit profile of the strip can be computed by considering that the such profile is the complement of that of the roll-gap, which is affected by wear, thermal expansion and distortion of the work rolls A computer model was developed to predict the profile of the roll-gap taking into account the thermal gradient within the work roll and the distortion caused by the acting forces. It was possible to establish a good correlation between the profiles of strips obtained from trials carried out on site, and the predictions of the model. The model allows for the prediction of the onset of shape defects from changes in the profile of rolled strips.

Rolling. Steel strip. Distortion. Thermal expansion. Dimensional quality.

\section{Modelización de la evolución del perfil y forma durante la laminación en caliente de cinta de acero}

\begin{abstract}
Resumen
Se requiere del control del perfil y forma para asegurar la calidad dimensional de la cinta laminada. La presencia de ondulaciones, ya sea en la orilla o al centro de la cinta, se atribuye a la inconsistencia entre el perfil de la sección transversal de la pieza a la entrada y a la salida, en un dado paso. El perfil de salida de la cinta se puede calcular al suponer que dicho perfil es el complemento del entrehierro, que es afectado por desgaste, expansión térmica y distorsión de los rodillos de trabajo. Un modelo matemático se desarrolló para predecir el perfil del entrehierro tomando en cuenta el gradiente térmico en el rodillo de trabajo y la distorsión producida por las fuerzas actuantes. Fue posible encontrar una buena correlación entre los perfiles de cintas obtenidos a partir de pruebas en planta y las predicciones del modelo. El modelo permite predecir el origen de defectos de forma a partir de cambios en el perfil de cintas laminadas.
\end{abstract}

Palabras clave Laminación. Cinta de acero. Distorsión. Expansión térmica. Calidad dimensional.

\section{INTRODUCTION}

The ability to produce consistent material is important to producers and consumers of steel goods. Such consistency is established not only in terms of their physical and mechanical properties, but also in their surface finish and dimensional quality. Various strategies are used in industry to achieve these characteristics, and one of the most important is that of process control, in which the variables and parameters that

\footnotetext{
* Trabajo recibido el día 3 de mayo de 2006 y aceptado en su forma final el día 19 de septiembre de 2006.

** Facultad de Ingeniería Mecánica y Eléctrica, Universidad Autónoma de Nuevo León, A.P. 149-F, 66451 San Nicolás de los Garza, N.L., Mexico

*** División Aceros Planos, Hylsa, S.A. de C.V., A.P. 996, 64000 Monterrey, N.L., Mexico.
} 

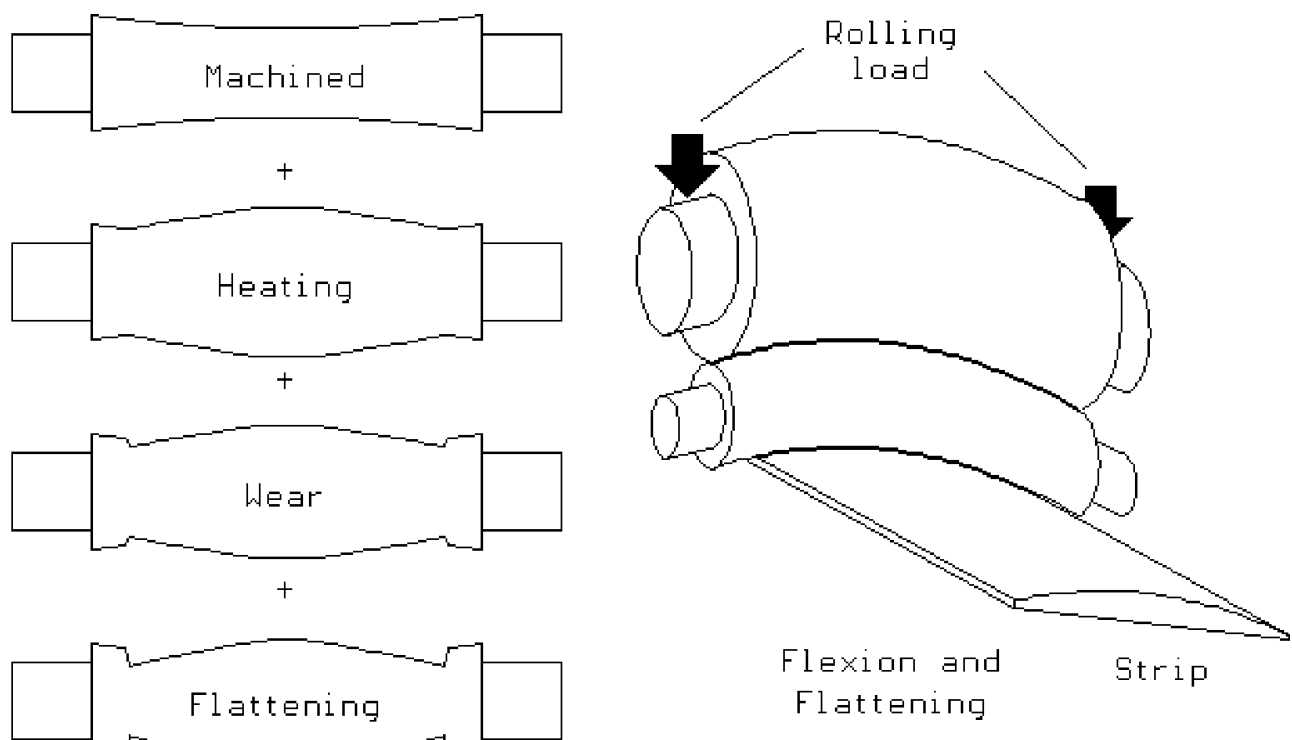

Figure 1. Schematic diagram showing the phenomena that affect the roll-gap profile.

Figura 1. Diagrama esquemático que muestra los fenómenos que influyen sobre el perfil del entrehierro.

may affect the quality of the product are maintained within narrow ranges. The traditional way to establish a target value, as well as the limits allowed, of a given variable are by trial and error, a method that in the short term only contributes to increase costs and decrease productivity. A different way to achieve the control required is by modelling the process from its fundamental basis, as modelling allows for a better description about causal relationships among different variables and parameters from a small number of experiments. Modelling also helps to reduce the time and trials required in the set-up of a given process that will be able to deliver new products, with the consequent improvement in efficiency.

Geometrical or dimensional control of rolled strips has become more important as the industry that consumes these goods change from manual control to highly automated systems. In this case, highly waved or cambered material might cause harm to people, damage to equipment or retard production as it clogs machines and comes out of trajectory. The work rolls, those in contact with the rolling stock, are machined with a certain crowning to assure that the strip remains in track. This machined crown will be affected by different phenomena as these tools are subjected to heating, due to friction and contact with the stock, which results in what is call the thermal crowning. Wear of the rolls is present due to abrasion and thermal fatigue; the worn profile can be heterogeneous and concentrated towards the region in which the edge of the strip gets in contact with the work roll. Furthermore, the rolling loads cause elastic flattening of the rolls, as well as elastic distortion of work and backup rolls ${ }^{[1-3]}$, figure 1 .

Shape defects such as the occurrence of waves either at the edges or centre of the strip will result by rolling of incompatible ingoing and outgoing profiles. Figure 2 shows that the only way to obtain a flat strip results when the reduction of thickness in a given pass is consistent along the profile, i.e. the reduction in crown (c) is equal to that in height (b). If, due to the causes mentioned above, the profile in the roll-gap is affected to such an extend that the reduction in height at the edges is higher than that at the centre, or vice versa, the strip will result in waves at either the centre or edges, figure 2.

The aim or this work is to present a model that predicts the tendency for the development of shape defects during production of hot rolled steel strip in a continuous mill. It is assumed that these defects occur when the profiles of the cross-section on entry and exit are incompatible. The model considers that the outgoing profile is the complement of the roll-gap profile, which is affected by the superposition of thermal and mechanical effects.

\section{MODELLING}

The relationship among the various parameters and variables involved in hot rolling of steel strip is complex. For instance, to compute the evolution of the cross-sectional profile and the onset of shape defects, other parameters, such as the temperature distribu- 


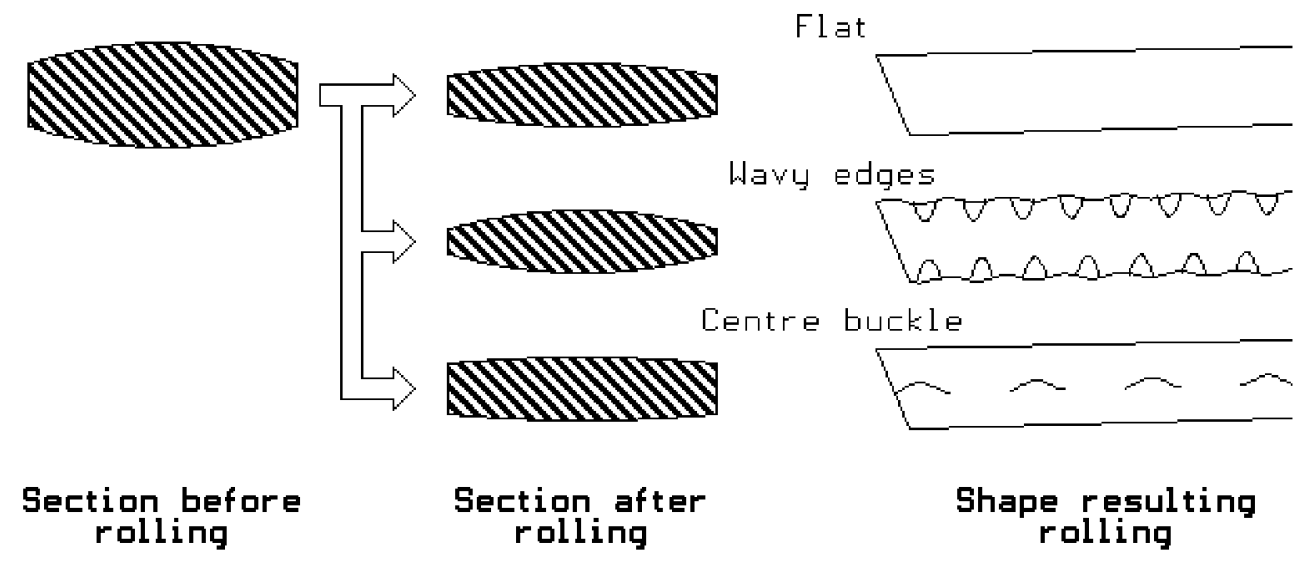

Figure 2. Schematic diagram showing that the occurrence of wavy edges or full centre is caused by inconsistent ingoing and outgoing cross-sectional profiles.

Figura 2. Diagrama esquemático que muestra como la incidencia de orilla o centro ondulado es causado por la inconsistencia entre los perfiles de entrada y salida.

tion within work rolls and strip should be known, the strength of the steel at the working temperature and the rolling schedule have to be accounted for, but these parameters depend on other variables such as the chemical composition and microstructure of the material. It is considered that the most important variable to model is temperature, due to the strong effect it exerts on microstructure, oxidation and strength of the steel being rolled. Another complication of hot rolling in a continuous mill is that as the stock thickness decreases its surface area increases, and the heat transfer rate is accelerated. This rate depends on the way heat is lost by the piece, as different mechanisms take place: convection and radiation (through an oxide layer) when the strip is on air, convection and boiling of water (from descailing and cooling headers), conduction to work rolls (through the thermal barrier that represents the oxide layer) during reduction. Temperature increase due to the adiabatic heating of deformation has to be considered when modelling. It is worth mentioning that the heat gained by the work rolls by conduction from the strip will cause their thermal expansion, which will affect the profile that was machined to them ${ }^{[2-7]}$.

The knowledge of the behaviour of the material while being deformed is required to obtain its strength at the working conditions (temperature, strain and strain rate), which is used to calculate the loads to which the stands, as a whole, are subjected ${ }^{[8 \text { and } 9]}$. This is important in relation to shape control as wear and flexion of the rolls depend on the applied load. It can be assumed that the profile of the cross-sectional area of the strip is the complement of that of the rollgap, which can be considered to be due to the super- position of the machined, flattening, thermal and worn crowns. Once this profile is known, it is possible to calculate the flexion and distortion to which the assembly made of back-up and work rolls is subjected to as the strip is deformed ${ }^{[10-14]}$.

Shape of the strip depends on the way the profile of the strip changes in every pass. The only way in which a flat strip will remain flat after a pass is by maintaining the ratio of the crown over height of the strip within narrow ranges, figure 2 . Waves on edges or at the centre of the strip, respectively, will appear when the $c / b$ ratio exceeds or goes below certain limits; this is more critical as the thickness of the strip over width increases, because the excess of material removed from the edges or the centre cannot be shifted sideways ${ }^{[7-14]}$. Figure 3 shows the graphic representation of the shape criterion given by:

$$
-80\left(\frac{h_{f}}{w}\right)^{1.86}<\Delta\left(\frac{c}{h}\right)<40\left(\frac{h_{f}}{w}\right)^{1.86}
$$

where $b$ is the thickness, $c$ the crowning, $w$ the width of the strip, $\Delta(c / h)$ is given by:

$$
\Delta\left(\frac{c}{h}\right)=\left(\frac{c_{f}}{h_{f}}-\frac{c_{0}}{h_{0}}\right)
$$

the sub indexes $o$ and $f$ are related to the values of the crown at the entry and exit of the pass. In this criterion the values below the limits will result in wavy edges and full centre when the values are above these limits. 


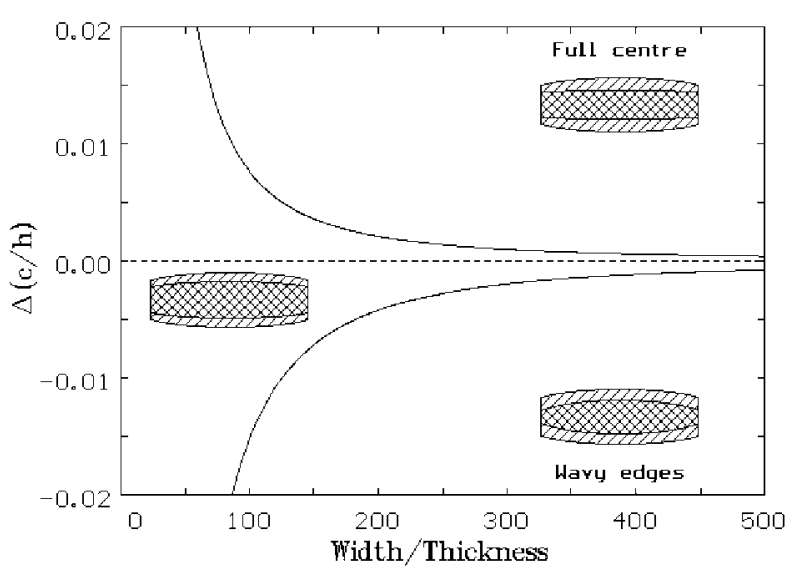

Figure 3. Graphic representation of the shape criterion given by equation (1).

Figura 3. Representación gráfica del criterio de forma dado por la ecuación (1).

The model developed to compute the changes in profile uses data obtained from the simulation of a six-stand continuous mill described elsewhere ${ }^{[9}$ and 16] This simulation provides information about the temperature distribution within strip and work rolls, as well as the strength of the steel. These data are used by the profile and shape model to predict the profile. It can be considered that a flat strip can be obtained by combining the prediction of the profile and an adequate roll-bending schedule, figure 4.
The width of the work and backup rolls is divided into $m$ segments, figure 5 . The width of these segments is $D w$, which is equal to that into which the strip was divided by the finite difference model developed to simulate the rolling process ${ }^{[9}$ and 16$]$. The thermal expansion of the segments corresponding to the work rolls is obtained by the addition of the individual expansion of each of the $n$ cells into which the roll was divided ${ }^{[9}$ and 16$]$ :

$$
\Delta R_{m}=\sum_{i=1}^{n} \alpha \cdot\left(T_{i}-T_{0}\right) \cdot \delta r_{i}
$$

where $\Delta R_{m}$ is the expansion of the $m$ section in which the radius of the work roll was divided, $\delta r_{i}$ is the size of the $i^{t h}$ cell, $T_{i}$ is the temperature at such cell, $T_{O}$ is the ambient temperature and $\alpha=4.2 \cdot 10^{-6} \mathrm{C}^{-1}$ is the coefficient of thermal expansion.

The distortion of the work roll is three-dimensional, but it can be simplified by assuming that the displacement of any point within the surface of the roll is the result of rigid body displacement, simple beam distortion of the roll axis, and distortion of the cross-sectional area by flexion and flattening ${ }^{[10-13]}$. Rigid body translation is calculated by adding the elongation of the mill stand and by the displacement of the roll neck from its bearing axis, but as it can be assumed that this displacement will be equal to all the segments within the roll, it can be neglected when computing its effects on shape.

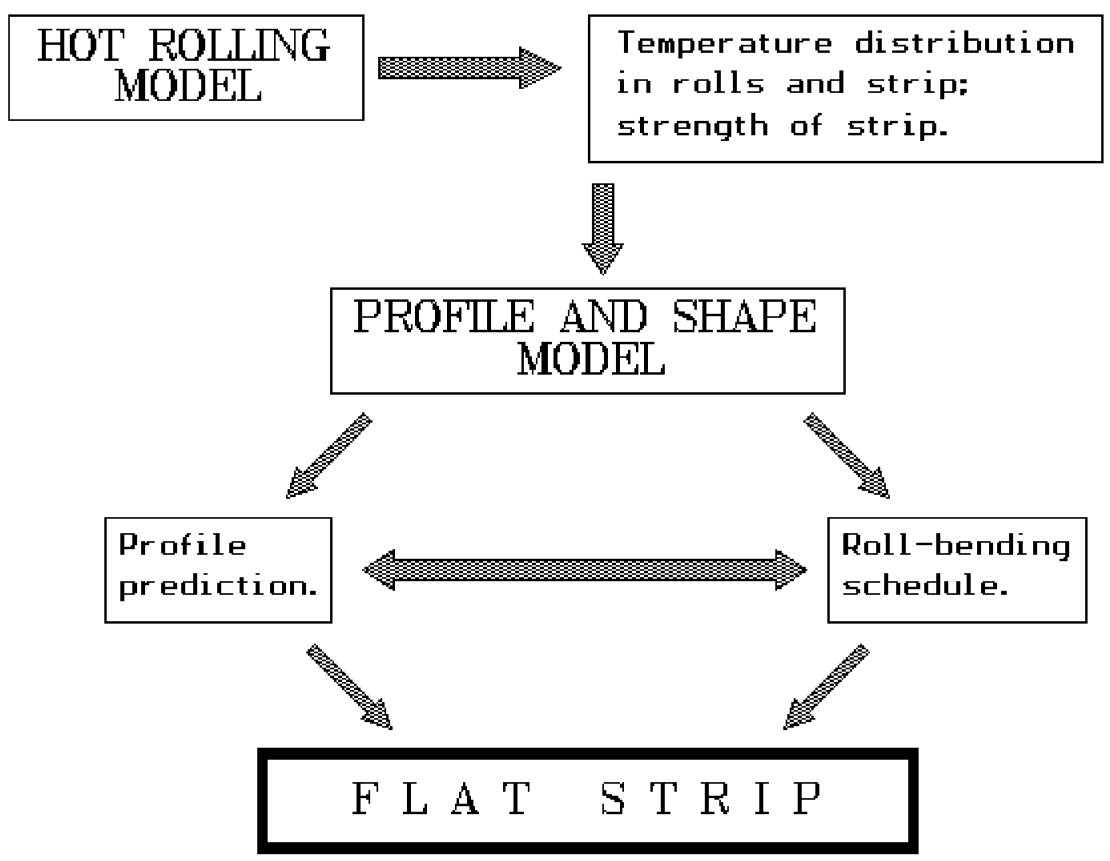

Figure 4. Schematic diagram showing the use of modelling to assure the production of flat strip.

Figura 4. Diagrama esquemático que indica el uso de modelos para asegurar la producción de cinta plana. 


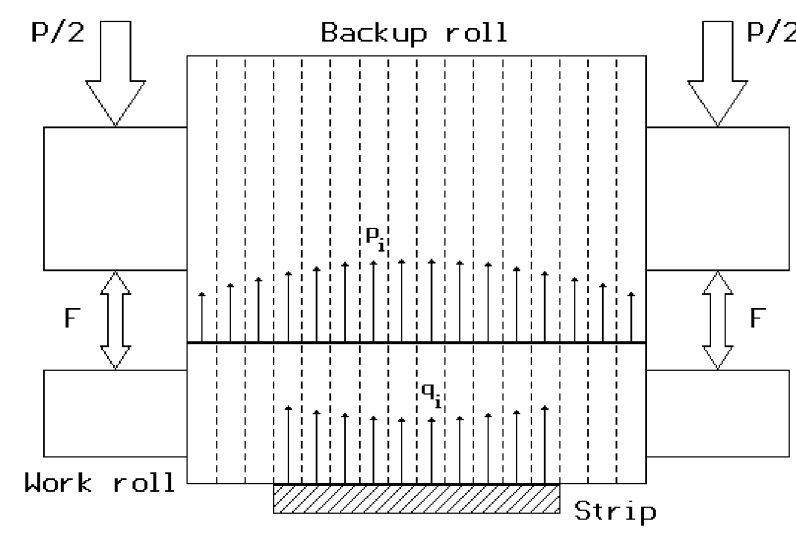

Figure 5. Schematic diagram of the segments into which the strip, work and backup rolls are divided; the forces and pressures acting on the system are indicated.

Figura 5. Diagrama esquemático que indica los segmentos en que la cinta y rodillos de apoyo y trabajo se dividen; se indican las fuerzas y presiones que afectan al sistema.

It is assumed that the backup roll will be deflected by the force transmitted by the work roll. The displacement of each point at the roll axis can be computed by the influence coefficients method described elsewhe$\mathrm{re}^{[10-13]}$ assuming that the force acting on each of the $m$ segments into which the roll was divided is concentrated at its centre, see figure 4 . If $p_{j}$ is the force per unit length acting at each $j$ section of $\Delta w$ width, then the effect of all the $p_{j} \Delta w$ acting on the $i^{\text {th }}$ section is given by:

$$
H_{b(i)}=\sum_{j=1}^{m} \alpha_{b i j} p_{j} \Delta w
$$

where $H_{b(i)}$ is the vertical displacement acting on the $i^{t h}$ sector of the backup roll and $a_{b i j}$ is the coefficient of influence in the backup roll at the $i^{\text {th }}$ section due to the force acting at the $j^{\text {th }}$ section. The displacements caused on the work roll are given by:

$$
H_{w(i)}=\sum_{j=1}^{n} \alpha_{b i j} q_{j} \Delta w-\sum_{j=1}^{m} \alpha_{w i j} p_{j} \Delta w
$$

where $H_{w(i)}$ is the vertical displacement caused on the $i^{t h}$ sector of the work roll, $a_{w i j}$ is the coefficient of influence in the work roll at the $i^{\text {th }}$ section due to the force acting at the $j^{\text {th }}$ section and $q_{j}$ are the force per unit length resulting from the contact between work roll and strip. It can be noticed that the sum of the $q_{j}$ terms is only from 1 to $n$, as this number corresponds to the segments into which the strip was divided.

Evaluation of the $p_{j}$ and $q_{j}$ pressures can be obtained by iteration ${ }^{[10]}$. This procedure can be simplified by using the method proposed elsewhere ${ }^{[12]}$, as the separation forces $(P)$ and the values of $q_{j}$ are known from the simulation of the rolling process ${ }^{[9}$ and 16] , and the force $(F)$ applied by the roll bending system is a parameter known during rolling.

Flattening of the work roll can be computed from the contact forces during rolling ${ }^{[13]}$.

$$
R_{i}^{\prime}=R_{i}\left[1+\frac{16\left(1-v^{2}\right)}{\pi E} \frac{q_{i}}{\Delta h_{i}}\right]
$$

where $R_{i}^{\prime}$ and $R_{i}$ are the work roll radius with and without deformation of the $i^{\text {th }}$ segment, $D b_{i}$ is the reduction of height at the $i^{\text {th }}$ segment, and $\mathrm{n}$ and $E$ are respectively Poisson's and Young's moduli. A similar equation is used to compute the flattening due to the contact between work and backup rolls ${ }^{[13]}$.

The algorithm used by the model determines the forces per unit length between the strip and work roll $\left(q_{i}\right)$ and those between rolls $\left(p_{i}\right)$, computes the thermal expansion at each segment of the work roll, equation. (3), then the flattening caused by the forces, equation (6), and the vertical displacements, equations (4) and (5).

Results of the model were validated by means of measurements of the profiles of sections cut from strips that were stopped within the mill. This is done with the last strip before changing work rolls, the mill is brought to a halt, the upper rolls are lifted and the part of the strip kept within the mill is cut into pieces while the remaining part is coiled. The advantage of these measurements is that they correlate to steady conditions, but the profile of the strip may be affected by wear. Predictions from the model were compared with measurements made on the front and back ends of coiled strips.

\section{RESULTS AND DISCUSSION}

Figures 6 to 8 show different data obtained from the simulation program that calculates heat and microstructural changes taking place while rolling ${ }^{[9}$ and 16$]$. Figures 6 and 7 show the temperature distribution within strip and work roll at the exit of the first pass. The pressure exerted by the strip during rolling is shown in figure 8 . The simulation corresponds to that for the production of low carbon steel strip of $0.82 \mathrm{~m}$ width. The reduction given in the first pass is of 0.47 and the work roll radius is of $238 \mathrm{~mm}$. The simulation assumes that the conditions during rolling are symmetrical and only half of the width is shown. The centre of the strip in figures 6 to 8 is drawn at zero width. The increase in pressure towards the edge of the strip, figure 8 , is associated with the lower temperatures predicted at this position, figure 6 . The temperature distribution within the work roll, figure 7 , is used to predict the thermal 


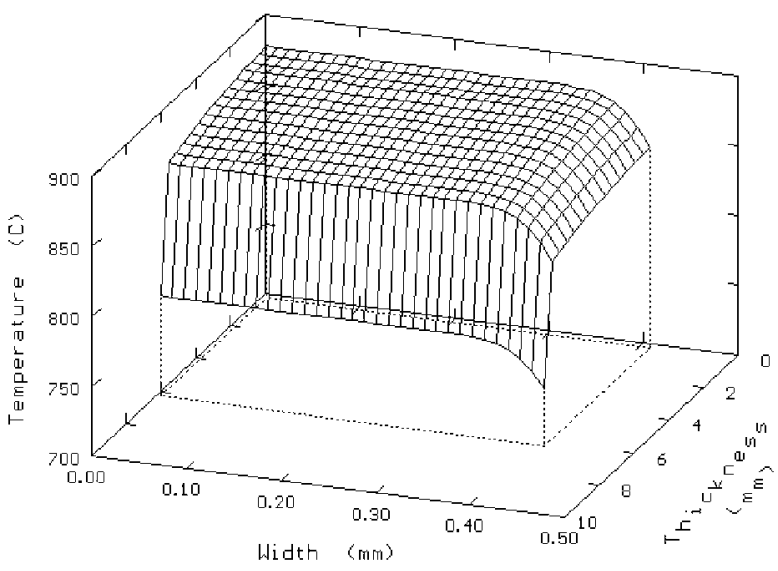

Figure 6. Temperature distribution predicted at the end of the first pass of rolling low carbon steel strip of $0.82 \mathrm{~m}$ width.

Figura 6. Distribución de temperatura predicha para el lado de la salida del primer paso de laminación para una cinta de $0,82 \mathrm{~m}$ de ancho.

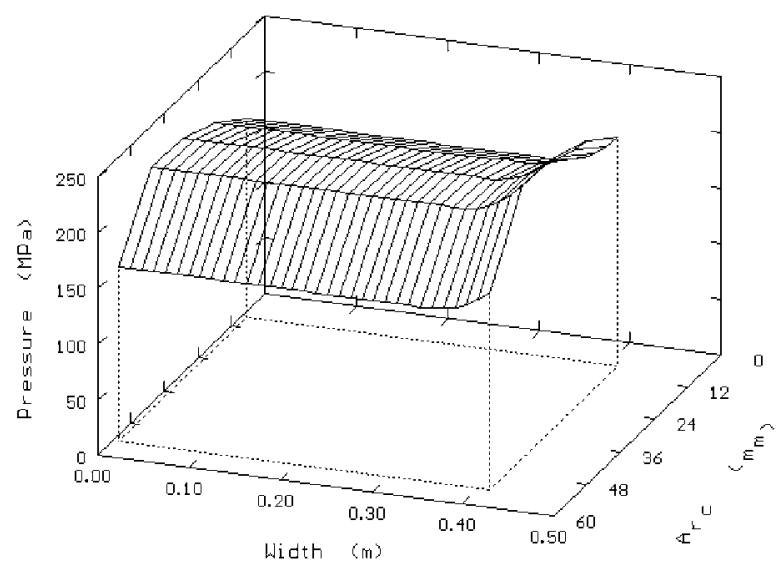

Figure 8. Pressure distribution predicted during the first pass of rolling.

Figura 8. Distribución de presión predicha para el primer pase de laminación.

expansion of the work roll, equation. (3). The pressure distribution, figure 8 is used to determine the values of $p_{j}$ and $q_{j}$, as well as the roll flattening predicted by equation. (6).

Figure 9 shows the variation in profile measured on sections cut after a transfer bar used to produce a strip of $991 \mathrm{~mm}$ in width and final thickness of 2.03 mm was stopped within the mill. The profiles are identified by the letter $\mathrm{F}$, and the corresponding number. Figure 10 shows the variation of the profile after normalizing it by dividing the individual values by the highest one. Figure 11 shows the normalized profile measured in a transfer bar that producing a strip of $953 \mathrm{~mm}$ in width and $3.02 \mathrm{~mm}$ in final thickness. It

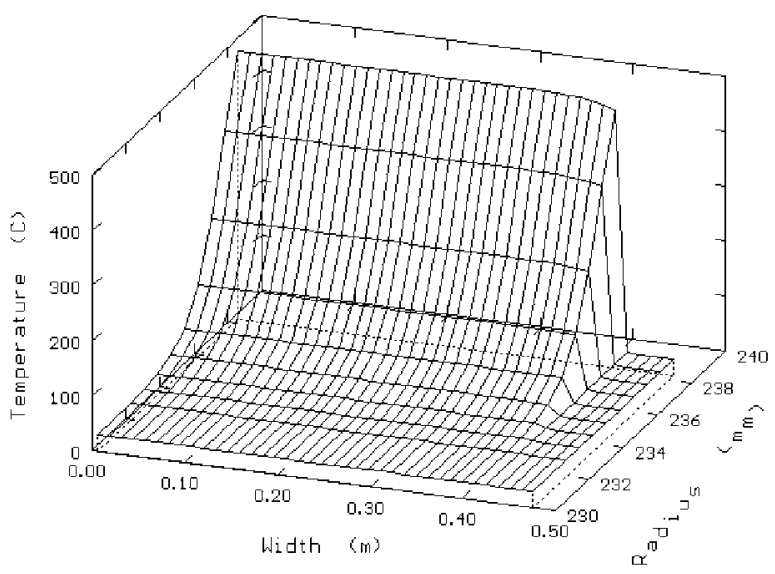

Figure 7. Temperature distribution predicted for a work roll of the first stand of a continuous mill at the exit of the strip.

Figura 7. Distribución de temperatura predicha para el rodillo de trabajo localizado en la primera estación de un molino continuo a la salida de la cinta.

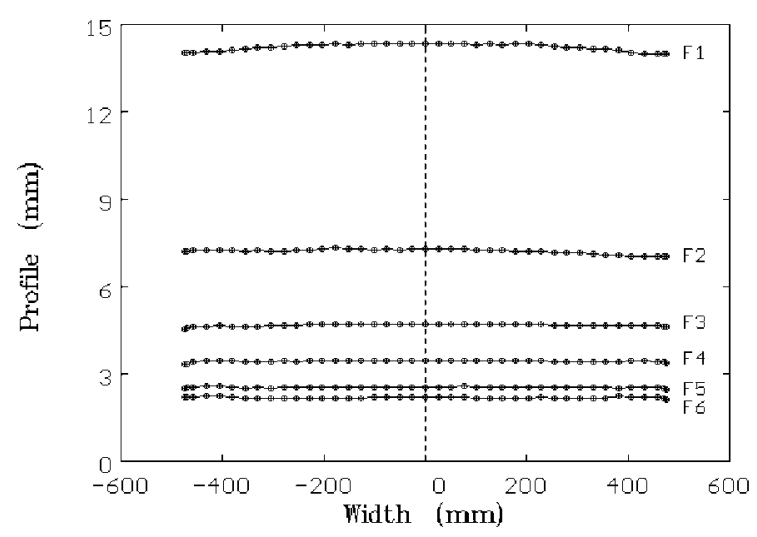

Figure 9. Measurements carried out on cuts from a transfer bar stopped within the mill when a strip of $991 \mathrm{~mm}$ in width and $2.03 \mathrm{~mm}$ final thickness was produced.

Figura 9. Mediciones realzadas en cortes de la barra de transferencia detenida en el molino cuando se producía cinta de $991 \mathrm{~mm}$ de ancho y 2,03 mm de espesor final.

can be observed in figures 10 and 11 the evidence of localized wear in the work rolls at the positions corresponding to the edges of the strip. The profile plotted at position 0 in figure 11 corresponds to that from the roughing mill.

Figure 12 shows the various profiles that the model computes for the work rolls in the first and last stands, F1 and F6 respectively. The diagram shows the machined profile, the expansion caused by the increase of temperature, and the distortion caused by flattening and flexion. The values were calculated assuming the operational conditions recorded during ro- 


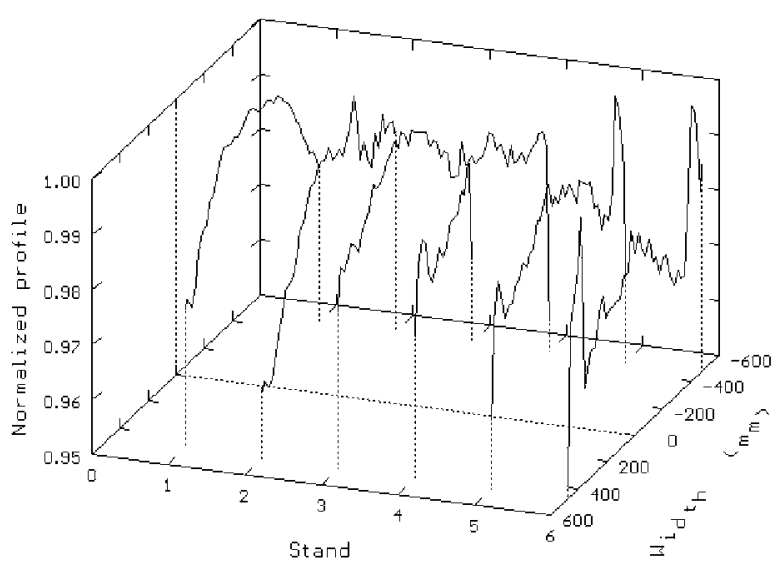

Figure 10. Profiles shown in figure. 9 normalized by dividing the individual values by the highest one.

Figura 10. Mediciones realzadas en cortes de la barra de transferencia detenida en el molino cuando se producía cinta de $991 \mathrm{~mm}$ de ancho y $2.03 \mathrm{~mm}$ de espesor final.

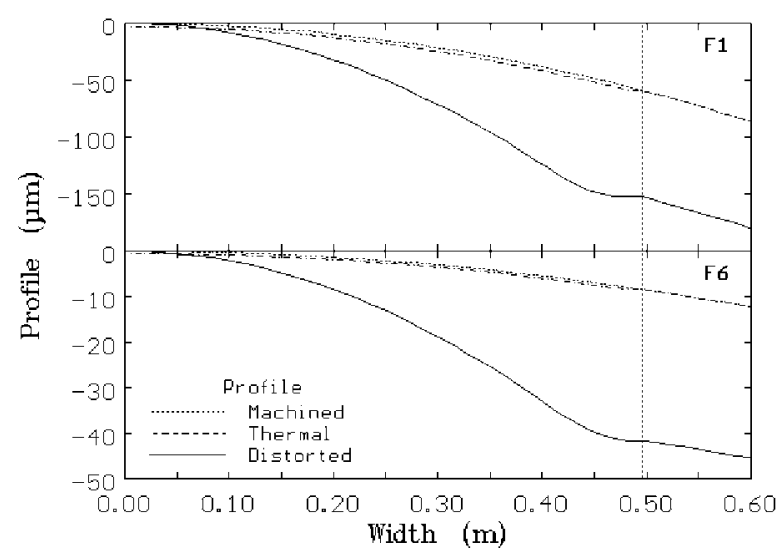

Figure 12. Superposition of thermal and mechanical effects to the profile machined to the work rolls in stands F1 and F6 as result of the production of strip of $991 \mathrm{~mm}$ in width and $2.03 \mathrm{~mm}$ of final thickness.

Figura 12. Superposición de los efectos térmicos y mecánicos sobre el perfil maquinado a los rodillos de trabajo de las estaciones F1 y F6 como resultado de la producción de cinta de $991 \mathrm{~mm}$ de ancho y 2,0e $\mathrm{mm}$ de espesor final.

lling the $991 \mathrm{~mm}$ in width and $2.03 \mathrm{~mm}$ final thickness strip shown in figures 9 and 10. The vertical, dotted, line indicates the width of the strip.

Figures 13 and 14 compare the profiles predicted by the model for the production of strips of 2.03 and $3.02 \mathrm{~mm}$, respectively, with the values measured in the samples cut from the strips that were stopped in the mill, see figures 9 to 11 . It can be appreciated a good agreement between measurements and predictions with the exception of the region close to the edge of the strip that is subjected to heavy localized we-

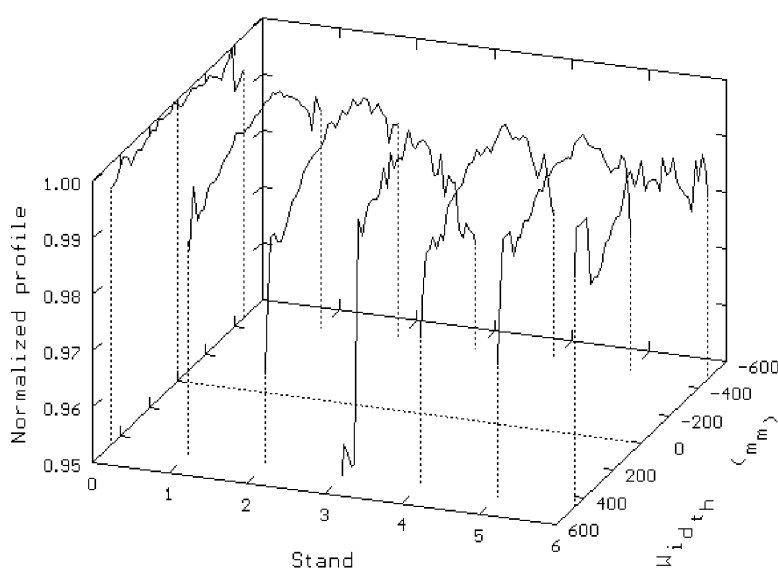

Figure 11. Normalized profiles of a transfer bar stopped while producing a strip of $953 \mathrm{~mm}$ in width and $3.02 \mathrm{~mm}$ final thickness.

Figura 11. Perfiles normalizados de una barra de transferencia detenida cuando se producía cinta de $953 \mathrm{~mm}$ de ancho y 3,02 mm de espesor final.

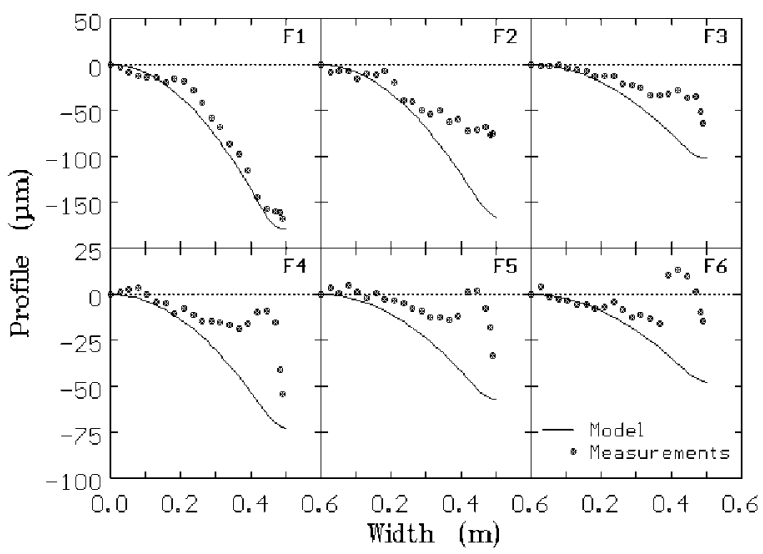

Figure 13. Comparison of the profiles predicted by the model and the measurements carried out on samples cut from strip of $991 \mathrm{~mm}$ in width and $2.03 \mathrm{~mm}$ of final thickness, see figures. 9 and 10 .

Figura 13. Comparación entre los perfiles predichos por el modelo y las mediciones realizadas sobre muestras de cinta de $991 \mathrm{~mm}$ de ancho y 2,03 mm de espesor final, ver figures. 9 y 10.

$\operatorname{ar}^{[17]}$, which is not yet contemplated by the model. Figure 15 compares the profiles predicted for strips of 2.03 and $3.02 \mathrm{~mm}$ with measurements made on the front and back ends of strips of similar width and thickness.

One of the aims of the model presented in this work is to evaluate the tendency for the development of shape defects during rolling, and to suppress them by improving the crowns that are machined in the work rolls, which depends on the rolling program, or 


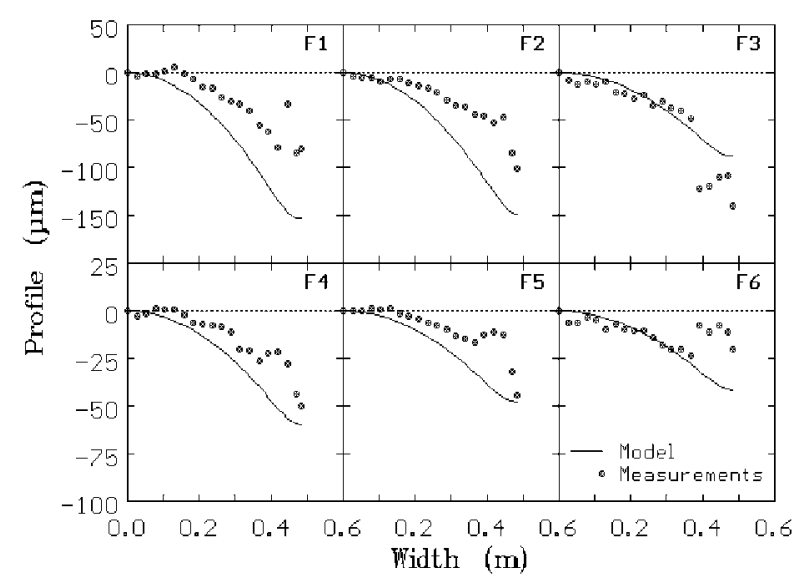

Figure 14. Comparison of the profiles predicted by the model and the measurements carried out on samples cut from strip of $953 \mathrm{~mm}$ in width and $3.02 \mathrm{~mm}$ of final thickness, see figure 11 .

Figura 14. Comparación entre los perfiles predichos por el modelo y las mediciones realizadas en muestras de cinta de 953 mm de ancho y 3.02 mm de espesor final, ver figura 11 .

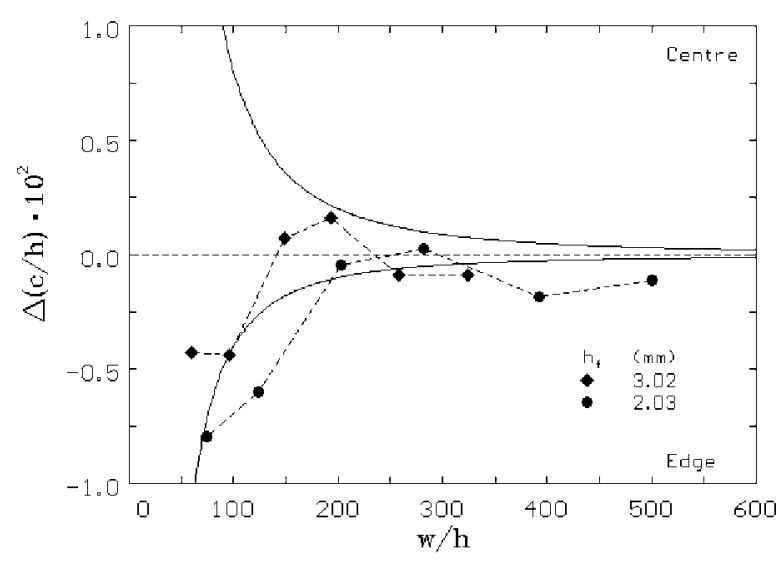

Figure 16. Tendency for the occurrence of shape defects in strips similar to those in figures 9 to 11 .

Figura 16. Tendencia a la generación de defectos de forma en cintas similares a las mostradas en las figuras 9 a 11 .

by developing an adequate strategy for roll bending, which will depend on the force balance during rolling. Such a tendency can be deduced by comparing the change in the crown over thickness ratio $(\Delta c / b)$ as a function of the width over thickness ratio $(w / h)$. Such a plot is shown in figure 16 for the case of the 2.03 and $3.02 \mathrm{~mm}$ strips. It can be observed a similar tendency for both strips in this figure as both strips may result in the occurrence of wavy edges. This defect may be corrected by dininishing the reduction at such places by reducing the crown machined in the fifth stand or by increasing the pressure of the roll bending system.

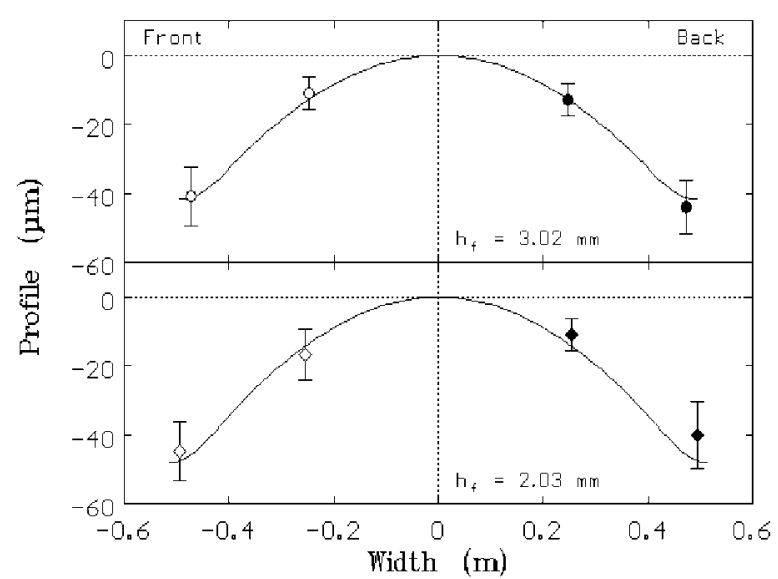

Figure 15. Comparison of the profiles predicted at the exit of the sixth stand and measurements on the front and back ends of strips similar to those shown in figures 9 to 11 .

Figura 15. Comparación entre los modelos predichos a la salida de la sexta estación y mediciones realizadas en las partes frontal y final de cintas similares a las mostradas en las figuras 9 a 11.

\section{CONCLUSIONS}

A model was developed to predict the effect that various phenomena exert on the roll-gap profile. This model uses information obtained from the simulation of the microstructural and thermal changes taking place during the production of hot rolled steel strip. Data from the simulation include the temperature distribution within work roll and strip and the pressure between the strip and work roll.

The present model considers that the profile of the cross-sectional area of the strip is the complement of that of the roll-gap, and it is found that it is able to evaluate the contribution of thermal and mechanical effects on the crown machined in the work rolls. However, it is required to quantify the wear localized at the region in which the edge of the strip gets in contact with the work roll.

The prediction of the change in the profile of the strip can be used to evaluate the tendency for the occurrence of shape defects during the production of hot rolled steel strip, and from them it is possible to establish a way to correct them.

\section{Acknowledgements}

The authors thank the support from the National Council for Science and Technology (CONACYT), México, and the Program for the Support of Science and Technology (PAICYT) of Universidad Autónoma de Nuevo León. 


\section{REFERENCES}

[1] W. ROBERTs, Cold Rolling of Steel, M. Dekker Inc., New York, 1978.

[2] W. Roberts, Hot Rolling of Steel, M. Dekker Inc., New York, 1982.

[3] V.B. GINZBURG, Steel Rolling: Theory and Practice, M. Dekker Inc., New York, 1989.

[4] R. COlÁs, R. PETROV AND Y. Houbaert, Handbook of Metallurgical Process Design, G.E. Totten, K. Fnatani and L. Xie (eds.), M. Dekker Inc., New York, 2004, pp. 47.

[5] F. Hollander, 1970, Mathematical Models in Metallurgical Process Development, Iron Steel Inst. Sp. Pub. 123, 46, 1970.

[6] S. Wilmotte, J. Mignon And M. ECONOMOpoulos, CRM Reps. 30 (1972).

[7] C.M. SEllars, Mat. Sc. Techn. 325 (1985).
[8] R. Colás, J. Mat. Proc. Tech. 62 (1996) 180

[9] R. COLÁs, Mat. Sc. Techn. 14 (1998) 388

[10] K.N. Shohet And N.A. Townsend, J. Iron Steel Inst. 206 (1968) 1088

[11] K.N. SHOHET AND N.A. Townsend, J. Iron Steel Inst. 209 (1971) 796

[12] V. Misaka and T. Yokoi, Proc. ICTIS, Suppl. Trans. ISIJ 11 (1971) 680

[13] S. Wilmotte, J. Mignon and M. Economopoulos, CRM Reports 30, 1972, 11.

[14] V.B. Ginzburg, High Quality Steel Rolling, Dekker, New York, 1993.

[15] G. Flemming, W. Hennig, F. Hofmann, F.-P. PlesChiutschingG, D. Rosental y J. SChWellenbach, Metall. Plant Techn. Int. 16 (1997) 64.

[16] R. Colás, Mod. Sim. Mat. Sci. Eng. 3 (1995) 437.

[17] A. Ziadi, F.J. Belzunce, C. Rodríguez and I. FerNÁNDEZ, Rev. Metal. Madrid 41 (2005) 111. 